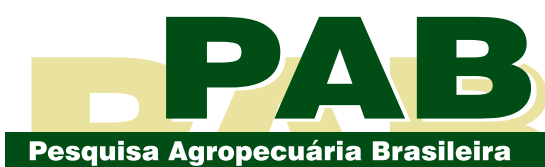

ISSN 1678-3921

Journal homepage: www.embrapa.br/pab

For manuscript submission and journal contents, access: www.scielo.br/pab
Luiz Henrique Torres Figueira ${ }^{(1 凶)}(\mathrm{D})$, Ana Lúcia Teodoro(2) (D),

Daniel Barros Cardoso(1) (iD,

William Gabriel Costa Sarmento(1) (iD, Dulciene Karla de Andrade Silva(1) (D), Mácio Farias de Moura(1) (iD, André Luiz Rodrigues Magalhães(1) (D) and Airon Aparecido Silva de Melo(1) (iD)

(1) Universidade Federal do Agreste de Pernambuco, Avenida Bom Pastor, s/no, Boa Vista, CEP 55292-270 Garanhuns, PE, Brazil.

E-mail: luiztorresfigueira@gmail.com, daniel.cardosozootecnista@gmail.com, williamsarmento2016@gmail.com, kakazoo50@gmail.com, maciof@yahoo.com.br, andre30036@gmail.com, aironuag@hotmail.com

(2) Instituto Federal de Educação, Ciência e Tecnologia do Piauí, Rodovia BR-407, Km 5 , s/no, Lagoa dos Canudos, CEP 64750-000 Paulistana, PI, Brazil.

E-mail: analuciazoo@yahoo.com.br

${ }^{凶}$ Corresponding author

Received

February 11, 2020

Accepted

October 01, 2020

How to cite

FIGUEIRA, L.H.T.; TEODORO, A.L.; CARDOSO, D.B.; SARMENTO, W.G.C.; SILVA D.K. de A.; MOURA, M.F. de; MAGALHÃES, A.L.R.; MELO, A.A.S. de. Qualitative parameters and nutritional potential of arboreal cotton silage. Pesquisa Agropecuária Brasileira, v.55, e01655, 2020. DOI: https://doi. org/10.1590/S1678-3921. pab2020.v55.01655.
Animal Science/ Original Article

\section{Qualitative parameters and nutritional potential of arboreal cotton silage}

\begin{abstract}
The objective of this work was to evaluate the qualitative parameters and nutritional potential of silage of arboreal cotton (Gossypium hirsutum) shoots. The experiment was carried out in a $4 \times 2$ factorial arrangement, for two silage forms (in natura or pre-dried), with four treatments, as follows: without additives (WA); with inoculant (WI); with $2 \%$ ground corn (GC); and with $2 \%$ ground corn with inoculant $(\mathrm{GC}+\mathrm{I})$. The fermentative quality and nutritional parameters of the silages were evaluated. Fermentative quality was better in the $\mathrm{WI}$ and $\mathrm{GC}+\mathrm{I}$ silages. The dry matter content was higher in the pre-dried silage, while the crude protein contents of in natura silage were higher in the WA and WI treatments. The lowest values of neutral detergent fiber and acid-digested lignin were observed in the WI treatment, for pre-dried silage. Total digestible nutrients and total volume of gas were higher in the pre-dried silage, in the WI and GC treatments, respectively. In vitro dry matter digestibility was lower in WA silage, in both forms. Silage of arboreal cotton associated with inoculant or with inoculant with ground corn shows a better fermentation profile and improves the energy and nutritional values, both in natura and pre-dried forms; however, in natura silage is less laborious for rural producers.
\end{abstract}

Index terms: Gossypium hirsutum, Lactobacillus plantarum, digestible nutrients, domestic ruminant, semiarid.

\section{Parâmetros qualitativos e potencial nutricional da silagem de algodão arbóreo}

Resumo - O objetivo deste trabalho foi avaliar os parâmetros qualitativos e o potencial nutricional da silagem da parte aérea do algodão (Gossypium hirsutum) arbóreo. O experimento foi realizado em arranjo fatorial $4 \times 2$, para duas formas de silagem (in natura ou pré-seca), com quatro tratamentos, conforme a seguir: sem aditivos (SA); com inoculante (CI); com $2 \%$ de milho moído (MM); e com 2\% de milho moído e inoculante (MM+I). Foram avaliados a qualidade fermentativa e os parâmetros nutricionais das silagens. A qualidade fermentativa foi melhor nas silagens CI e MM+I. Os teores de matéria seca foram maiores na silagem pré-seca, enquanto a proteína bruta na silagem in natura foi maior nos tratamentos SA e CI. Os menores valores de fibra em detergente neutro e lignina digerida em ácido foram observados no tratamento CI, para a silagem pré-seca. Os nutrientes digestíveis totais e o volume total de gás foram maiores na silagem pré-seca, nos tratamentos CI e MM, respectivamente. A digestibilidade in vitro da matéria seca foi menor na silagem SA, nas duas formas. A silagem de algodão arbóreo associada ao inoculante ou ao inoculante com milho moído apresenta o melhor perfil fermentativo e melhora o valor energético e nutricional, tanto na forma in natura como na pré-seca; porém, a silagem in natura é menos trabalhosa para os produtores rurais.

Termos para indexação: Gossypium hirsutum, Lactobacillus plantarum, nutrientes digestíveis, ruminantes domésticos, semiárido. 


\section{Introduction}

The ruminant production in the Northeastern Brazil is an important income-generating activity for the local population, that contributes to the economic and social development of the region. The livestock activity present in this region faces some obstacles because the availability and quality of forage resources are affected by rainfall scarcity and irregularities of rainfall, high annual evaporation, and shallow soils with low moisture retention capacity (Silva et al., 2014). In this scenario, research should be directed to alternative foods that are adapted to its environmental conditions. In the Semiarid region there is no perfect forage alternative, therefore, outputs to alleviate the situation of farmers in the dry season are sought, such as the production and conservation of native or adapted forage species, in order to increase the productive efficiency (Campos et al., 2017).

Among the forage alternatives for nutrient supply to meet the nutritional requirements of ruminant animals raised in this region, the use of several species of plants that have forage potential are outstanding, but their nutritional characteristics are generally not known, as is the case for arboreal cotton [Gossypium hirsutum var. marie-galante (G.Watt) J.B.Hutch.]. This plant has a high level of genetic diversity in this region (Menezes et al., 2017). In years of intense droughts, after the harvesting of feathers, the use of plant leaves in the diets contributes to the nutritional supplementation to feed cattle (Menezes et al., 2015, 2017).

The silage of the aerial part of arboreal cotton may have good potential to be used, mainly associated with spineless cactus in the diets for ruminant animals, to correct the deficiency of neutral detergent fiber, dry matter, and crude protein of this cactus (Silva et al., 2017; Moraes et al., 2019). At first, it is necessary to know the nutritional characteristics of arboreal cotton, as this silage can be used as roughage supplementation, or associated with concentrated foods. There are few studies in the literature on the quality of arboreal cotton silage, so it is necessary to know its nutritional quality for the correct use in the diets for ruminant animals.

The objective of this work was to evaluate the qualitative parameters and nutritional potential of silage of the aerial part of arboreal cotton.

\section{Materials and Methods}

Samples for the ensiling process were collected from a cultivated area of arboreal cotton, situated at the experimental farm of the Universidade Federal Rural de Pernambuco (UFRPE), in the municipality of Garanhuns, in the state of Pernambuco, Brazil (08 $58^{\prime} 43^{\prime \prime} \mathrm{S}, 36^{\circ} 27^{\prime} 15^{\prime \prime} \mathrm{W}$, at $822.76 \mathrm{~m}$ altitude). The region's climate is classified as a tropical type Aw, according to the Köppen-Geiger's classification, with $21.2^{\circ} \mathrm{C}$ mean annual temperature, and from 75 to $83 \%$ relative air humidity. The soil of the experimental area is characterized as "franco-argilo-arenoso" (Santos et al., 2018), which corresponds to a sandy loam soil.

The point for the collection of plants was chosen 120 days after the cutting, at approximately $50 \mathrm{~cm}$ height, corresponding to $1,260.5 \mathrm{~m}^{2}$ area, with a total of 1,296 plants. To the ensiling process of arboreal cotton, the aerial part of the plants (leaves and branches) was collected, and the material was chopped in a stationary machine MCln 2.0e (Laboremus, Campina Grande, $\mathrm{PE}$, Brazil) into $1 \mathrm{~cm}$ particles. Part of the material was exposed to the sun for 4 hours (pre-dried), then ensiled, and the other part was ensiled soon after the material was chopped. The forage mass was homogenized with additives of the respective treatments, then it was immediately compacted, using a wood compactor, and stored in experimental polyvinyl chloride (PVC) tube silos, containing a Bunsen type valve at the top, and sand at the bottom; tube measures were $53 \mathrm{~cm}$ long by $10 \mathrm{~cm}$ diameter. The density used was 650 to $700 \mathrm{~kg} \mathrm{~m}^{-3}$ of fresh matter. The silos were maintained in an environment at $20.4^{\circ} \mathrm{C}$ and $70 \%$ humidity.

Two forms of silage (in natura and pre-dried) were performed, with five replicates (tube silos), and four treatments were used for each form of silage, as follows: WA, without additives; WI, with bacterial inoculant; GC, with $2 \%$ ground corn; and $(\mathrm{GC}+\mathrm{I})$, $2 \%$ ground corn + bacterial inoculant. The bacterial inoculant was composed of strains of Lactobacillus plantarum and Pediococcus pentosaceus, and the amount used was $1 \mathrm{~g}$ inoculant per ton of forage mass. Before the ensiling process for in natura and pre-dried forms, arboreal cotton had respectively: 222.2 and $357.8 \mathrm{~g} \mathrm{~kg}^{-1}$ dry matter (DM), expressed as grams per kilogram of fresh matter; 95.6 and $94.9 \mathrm{~g} \mathrm{~kg}^{-1} \mathrm{DM}$ of ash; 244.8 and $239.8 \mathrm{~g} \mathrm{~kg}^{-1} \mathrm{DM}$ of crude protein (CP); 15.7 and $19.8 \mathrm{~g} \mathrm{~kg}^{-1} \mathrm{DM}$ of ether extract (EE); 510.3 and $495.3 \mathrm{~g} \mathrm{~kg}^{-1} \mathrm{DM}$ of neutral detergent fiber (NDF); 
and 269.8 and $239.3 \mathrm{~g} \mathrm{~kg}^{-1} \mathrm{DM}$ of acid detergent fiber (ADF).

The weighing was done before and after fermentation to quantify gas losses, and sand was also weighed to quantify effluent losses. The silos were opened 30 days after the ensiling process. After opening, the silage was pressed, using a manual press to extract the liquid, which whose $\mathrm{pH}$ was measured by using a digital pH meter (PHS3BW, Bel Engineering, Monza, Italy). Ammoniacal nitrogen $\left(\mathrm{NH}_{3}-\mathrm{N}\right)$ was quantified by the calorimetric method with indophenol formation (Chaney \& Marbach, 1962).

Silage was homogenized and sampled, and $10 \mathrm{~cm}$ of it was discarded from the bottom and top of the silo. Subsequently, the samples were pre-dried in a forcedair ventilation oven Te-394/2 (Tecnal, Piracicaba, SP, Brazil), at $55^{\circ} \mathrm{C}$ for 72 hours, and ground in MA 580 Wiley knife mill (Marconi, Piracicaba, SP, Brazil), with $1 \mathrm{~mm}$ and $2 \mathrm{~mm}$ sieves. The analyses concerning the chemical composition of dry matter (DM), organic matter (OM), ash, crude protein (CP), and ether extract (EE) were performed according to AOAC (Helrich, 1990). The NDF, ADF, and acid-digested lignin (ADL) were determined according to Van Soest et al. (1991). Corrections of NDF for ash and protein to obtain NDFap were performed according to Mertens (2002) and Licitra et al. (1996), respectively. The hemicellulose (HEM) and cellulose (CEL) fractions were estimated by the equations HEM $=\mathrm{NDF}-\mathrm{ADF}$, and $\mathrm{CEL}=\mathrm{ADF}$ - ADL, respectively.

Total carbohydrate (TC) fractions were estimated by $\mathrm{TC}=100-(\mathrm{CP}+\mathrm{EE}+\mathrm{ash})$, according to Sniffen et al. (1992). Nonfibrous carbohydrate (NFC), corresponding to the fractions $\mathrm{A}+\mathrm{B} 1$, was measured by the equation $\mathrm{NFC}=100 \times(\mathrm{CP}+\mathrm{NDFap}+\mathrm{EE}+\mathrm{MM})$. The $\mathrm{B} 2$ fraction, which corresponds to the available fraction of fiber, was estimated by the difference between NDFap and the fraction $\mathrm{C}$. The fraction $\mathrm{C}$, corresponding to indigestible NDFap was determined according to the equation: $\mathrm{C}=(100 \times \mathrm{NDFap}(\% \mathrm{DM})$ $\times 0.01 \times$ lignin $(\%$ NDFap $) \times 2.4) / \mathrm{TC}(\% \mathrm{DM})$.

The levels of nonprotein nitrogen (NPN), neutral detergent insoluble protein (NDIP), and acid detergent insoluble protein (ADIP) were determined according to Licitra et al. (1996). Fraction A was obtained by the difference between total $\mathrm{N}$ and insoluble $\mathrm{N}$ (residual) in trichloroacetic acid (10\%). The fraction $\mathrm{B} 1+\mathrm{B} 2$ was calculated from the equation:
$\mathrm{B} 1+\mathrm{B} 2=100-(\mathrm{A}+\mathrm{B} 3+\mathrm{C})$. Fraction $\mathrm{B} 3$ was obtained by the difference between NDIP and ADIP, and fraction $\mathrm{C}$ was considered as ADIP.

Total digestible nutrient values (TDN) were estimated according to the National Research Council (NRC, 2001). In vitro dry matter digestibility (IVDMD) was obtained according to the two-stage methodology described by Tilley \& Terry (1963) with changes proposed by Holden (1999). To measure the gas production kinetics, the in vitro technique was applied, using a pressure transducer according to Theodorou et al. (1994), in which $1 \mathrm{~g}$ of an air-dried sample (milled at $2 \mathrm{~mm}$ ) was incubated in flasks $(160 \mathrm{~mL})$ together with $90 \mathrm{~mL}$ of nutrient medium, and $\mathrm{CO}_{2}$ was then injected with $10 \mathrm{~mL}$ of ruminal fluid from two rumen-fistulated 6-year-old female cattle Girolando (5/8 Holstein x Gyr). Then the flasks were sealed with rubber stoppers and aluminum seals.

Subsequently, the flasks were incubated in a greenhouse that simulated a constant temperature rumen of $39^{\circ} \mathrm{C}$. Cumulative gas production was estimated by measuring the pressure of the gases produced during the fermentative process, using a pressure transducer Logger AG100 (Agricer, São Paulo, SP, Brazil), in times 0, 2, 4, 6, 8, 10, 12, 15, 18, $21,24,30,36,42$, and 48 hours after incubation.

The pressure per inch (PSI) was transformed into milliliters $(\mathrm{mL})$ through the equation: Gas production $(\mathrm{mL})=5.1612 \times$ PSI $-0.3017, \mathrm{r}^{2}=0.9873$, generated in the Production Laboratory (LPG) of the Universidade Federal do Agreste de Pernambuco (Ufape) based on 937 observations, and adjusted for white and incubated dry matter. The cumulative gas production data were adjusted by the bicompartmental logistic model (Schofield et al., 1994) using the procedure NLMIXED of SAS.

$\mathrm{V}_{\mathrm{t}}=\frac{\mathrm{V}_{\mathrm{f} 1}}{1+\mathrm{e}^{[2-4 \times \mathrm{kd} 1 \times(\mathrm{T}-\mathrm{L})]}}+\frac{\mathrm{V}_{\mathrm{f} 2}}{1+\mathrm{e}^{[2-4 \times \mathrm{kd} 2 \times(\mathrm{T}-\mathrm{L})]}}+\varepsilon$,

in which: $V_{t}$ is the accumulated volume over time $t ; V_{f 1}$ is the maximum volume of gas for the fast digestion fraction (NFC); $\mathrm{Kd}_{1}\left(\mathrm{~h}^{-1}\right)$ is the degradation rate of the rapid digestion fraction; $\mathrm{L}$ is latency in hours; $\mathrm{T}$ is time (h); $\mathrm{V}_{\mathrm{f} 2}$ is the maximum volume of gas for the slow digestion fraction $(\mathrm{FC}) ; \mathrm{kd}_{2}\left(\mathrm{~h}^{-1}\right)$, the specific rate of gas production by fraction degradation (FC).

Data were subjected to the analysis of variance, and the means were compared by the Tukey's test, at 5\% 
probability, through the statistical program SAS (SAS Institute Inc., Cary, NC, USA).

\section{Results and Discussion}

The $\mathrm{pH}$ values in natura and pre-dried silage were smaller in the WI and GC+I treatments (Table 1). However, the $\mathrm{pH}$ values in all treatments described here were higher than the ideal range from 3.8 to 4.2 for a good fermentation proposed by McDonald et al. (1991). Treatments with the bacterial inoculant had the lowest $\mathrm{pH}$ values. This result suggests that in these treatments there was a larger population of lactic acidproducing bacteria, which favored a greater reduction of $\mathrm{pH}$. Higher lactic acid content in the treatments without bacterial inoculation can be attributed to the greater acidification power of acetic and butyric acids. High $\mathrm{pH}$ values indicate a possible higher production of acetic and butyric acid, which are typical acids of undesirable fermentations (Pinho et al., 2013; Bezerra et al., 2019).

Although the $\mathrm{pH}$ values were above the ideal range, this result did not compromise the quality of silage. Therefore, the gas losses of in natura silage did not differ among treatments, but those of pre-dried silage showed the highest values in the WA and GC treatments. Between the two forms of silage, the gas losses in the pre-dried silage was higher than that of in natura silage in all treatments (Table 1). The lower production of gases of in natura silage may have

Table 1. Fermentative characteristics of the different treatments applied to arboreal cotton silage [Gossypium hirsutum var. marie-galante (G.Watt) J.B.Hutch. ${ }^{(1)}$.

\begin{tabular}{llllll}
\hline Trait & Silage & \multicolumn{4}{c}{ Treatment $^{(2)}$} \\
\cline { 3 - 6 } & & \multicolumn{1}{c}{$\mathrm{WI}$} & \multicolumn{1}{c}{$\mathrm{GC}$} & $\mathrm{GC}+\mathrm{I}$ & $\mathrm{WA}$ \\
\hline \multirow{2}{*}{$\mathrm{pH}$} & In natura & $4.69 \mathrm{Ca}$ & $5.16 \mathrm{Ba}$ & $4.46 \mathrm{Db}$ & $5.25 \mathrm{Aa}$ \\
& Pre-dried & $4.51 \mathrm{Db}$ & $4.90 \mathrm{Bb}$ & $4.63 \mathrm{Ca}$ & $5.20 \mathrm{Aa}$ \\
$\mathrm{Gas}$ & In natura & $1.06 \mathrm{Ab}$ & $1.26 \mathrm{Ab}$ & $1.05 \mathrm{Ab}$ & $1.28 \mathrm{Ab}$ \\
losses $^{(3)}$ & Pre-dried & $2.16 \mathrm{Ba}$ & $2.59 \mathrm{ABa}$ & $2.11 \mathrm{Ba}$ & $3.04 \mathrm{Aa}$ \\
Effluent $^{(2)}$ & In natura & $2.46 \mathrm{ABa}$ & $2.31 \mathrm{Ba}$ & $2.59 \mathrm{ABa}$ & $3.08 \mathrm{Aa}$ \\
losses $^{(4)}$ & Pre-dried & $2.20 \mathrm{Aa}$ & $2.18 \mathrm{Aa}$ & $2.17 \mathrm{Aa}$ & $2.35 \mathrm{Ab}$ \\
& In natura & $0.61 \mathrm{Ba}$ & $1.02 \mathrm{Aa}$ & $0.63 \mathrm{Bb}$ & $0.75 \mathrm{ABb}$ \\
$\mathrm{NH}_{3}-\mathrm{N}$ & Pre-dried & $0.79 \mathrm{Ba}$ & $1.20 \mathrm{Aa}$ & $0.86 \mathrm{Ba}$ & $1.24 \mathrm{Aa}$ \\
\hline
\end{tabular}

(1) Means followed by equal letters, uppercases in the rows and lowercases in the columns, do not differ by Tukey's test, at $5 \%$ probability. ${ }^{(2)} \mathrm{WI}$, with bacterial inoculant; GC, $2 \%$ ground corn; GC+I, $2 \%$ ground corn + bacterial inoculant; WA, without additives. ${ }^{(3)}$ Percentage of dry matter $(\% \mathrm{DM}) .{ }^{(4)}$ Ensiled fresh matter $\left(\mathrm{kg} \mathrm{Mg}^{-1} \mathrm{FM}\right) . \mathrm{NH}_{3}-\mathrm{N}$, ammonia nitrogen $(\%$ of Total $\mathrm{N})$. occurred because of the lower presence of Clostridium bacteria during fermentation, as they produce butyric acid and $\mathrm{CO}_{2}$, and their presence in the fermentation process is not desired. The values resulting of the two silages with their respective treatments are considered low, which is an indication of silage quality.

The effluent losses were higher in the treatments WI, WA, and GC+I of in natura silage. These results can be attributed to the higher moisture content present in these treatments (Table 1). The lowest value of effluent losses occurred in the GC treatment, as a result of the use of ground corn as moisture absorbing additive, which favored the reduction of the losses of the ensiled material. The use of absorbent additives is one of the main techniques used to soften the effluent production in the ensiled material, reducing secondary fermentation, as they favor the increases of both dry matter content and nutritional quality (Andrade et al., 2012; Bezerra et al., 2019). Consequently, regarding the DM content, in natura and pre-dried silage, $\mathrm{GC}+\mathrm{I}$ showed higher values than the other treatments (Table 2).

The lower values for effluent losses in pre-dried silage may be related to the shrinkage that was performed before silage. The pre-dried is an important technique that aims to prevent nutrient losses through percolation in the ensiled material. Besides that, the wilting is a practice that helps increase the DM content and reduces the effluent production (Corrêa et al., 2016). Therefore, the DM of pre-dried silage was higher than that of in natura silage (Table 2).

Ammonia nitrogen $\left(\mathrm{NH}_{3}-\mathrm{N}\right)$, expressed as a percentage of total nitrogen (\% total $\mathrm{N})$ showed differences between treatments in the in natura silage, in which the treatment with ground corn (GC) was higher than the other treatments (Table 1). In the form of pre-dried silage, the treatments without additive (WA) and ground corn (GC) had higher values of ammonia nitrogen than the other treatments, therefore, showing good preservation of proteins and nitrogen compounds in the two analyzed materials. McDonald et al. (1991) reported that concentrations below $10 \%$ in this ratio indicates silage of excellent quality.

The CP contents of in natura silage were higher in the treatments WA, GC, and WI, and the lowest $\mathrm{CP}$ values were found in the $\mathrm{GC}+\mathrm{I}$ treatment (Table 2). The treatments in which corn was added as an additive, the protein content was lower, as the low content of $\mathrm{CP}$ 
in corn led to a dilution effect of this nutrient in the silage. In comparison between silages, the treatments WA and WI of in natura silage were superior to those of pre-dried silage (Table 2). The present study corroborates the findings of Bergamaschine et al. (2006) on 'Marandu' Brachiaria brizantha. The authors observed a $20.1 \%$ reduction in the $\mathrm{CP}$ content of the material subjected to pre-drying under the sun for 4 hours, which was attributed to soluble protein losses due to the extravasation of cellular content. The CP concentrations were higher than the values described by Silva et al. (2015) and Coutinho et al. (2015), who evaluated silage of arboreal species and herbaceous legumes present in the Brazilian Semiarid region.

There was no difference for neutral detergent fiber (NDF) between treatments of in natura silage. However, in pre-dried silage, the WA, GC, and GC+I showed higher NDF values than the other treatments, and the WI showed the lowest NDF content (Table 2). In the two forms of silage, the average NDF values of treatments were lower concerning Clitoria ternatea, Leucaena leucocephala, Bauhinia cheilantha, and

Table 2. Chemical composition and total digestible nutrients of different treatments applied to silage of arboreal cotton [Gossypium hirsutum var. marie-galante (G.Watt) J.B.Hutch. $]^{(1)}$.

\begin{tabular}{|c|c|c|c|c|c|}
\hline \multirow[t]{2}{*}{ Trait $^{(2)}$} & \multirow[t]{2}{*}{ Silage } & \multicolumn{4}{|c|}{ Treatment $^{(3)}$} \\
\hline & & WI & GC & $\mathrm{GC}+\mathrm{I}$ & WA \\
\hline \multirow{2}{*}{$\begin{array}{l}\text { Dry matter (DM, } \mathrm{g} \mathrm{kg}^{-1} \\
\text { of fresh matter) }\end{array}$} & In natura & $232.9 \mathrm{Bb}$ & $228.4 \mathrm{BCb}$ & $248.7 \mathrm{Ab}$ & $217.7 \mathrm{Cb}$ \\
\hline & Pre-dried & $355.8 \mathrm{Aa}$ & $355.2 \mathrm{Aa}$ & $352.8 \mathrm{Aa}$ & $344.4 \mathrm{Aa}$ \\
\hline \multirow{2}{*}{$\begin{array}{l}\text { Organic mater } \\
\left(\mathrm{OM}, \mathrm{g} \mathrm{kg}^{-1} \text { of } \mathrm{DM}\right)\end{array}$} & In natura & $905.6 \mathrm{Ba}$ & 908.7Aa & $904.6 \mathrm{Bb}$ & $903.5 \mathrm{Ba}$ \\
\hline & Pre-dried & $905.5 \mathrm{ABa}$ & $907.5 \mathrm{Aa}$ & $907.3 \mathrm{Aa}$ & $905.0 \mathrm{Ba}$ \\
\hline \multirow{2}{*}{$\begin{array}{l}\text { Crude protein } \\
\left(\mathrm{CP}, \mathrm{g} \mathrm{kg}^{-1} \text { of } \mathrm{DM}\right)\end{array}$} & In natura & $243.2 \mathrm{Aa}$ & $236.7 \mathrm{ABa}$ & $227.7 \mathrm{Ba}$ & $245.1 \mathrm{Aa}$ \\
\hline & Pre-dried & $232.7 \mathrm{Ab}$ & $233.1 \mathrm{Aa}$ & $235.6 \mathrm{Aa}$ & $231.8 \mathrm{Ab}$ \\
\hline \multirow{2}{*}{$\begin{array}{l}\text { Ether extract } \\
\left(\mathrm{EE}, \mathrm{g} \mathrm{kg}^{-1} \text { of } \mathrm{DM}\right)\end{array}$} & In natura & $20.7 \mathrm{Aa}$ & $22.2 \mathrm{Aa}$ & $22.3 \mathrm{Aa}$ & $16.2 \mathrm{Aa}$ \\
\hline & Pre-dried & $20.6 \mathrm{Aa}$ & $19.7 \mathrm{Aa}$ & $15.3 \mathrm{Ab}$ & $19.8 \mathrm{Aa}$ \\
\hline \multirow{2}{*}{$\mathrm{NDF}^{(2)}$} & In natura & $540.4 \mathrm{Aa}$ & $558.8 \mathrm{Aa}$ & $529.1 \mathrm{Aa}$ & $565.1 \mathrm{Aa}$ \\
\hline & Pre-dried & $523.6 \mathrm{Ba}$ & $528.1 \mathrm{ABa}$ & $557.3 \mathrm{ABa}$ & $569.1 \mathrm{Aa}$ \\
\hline \multirow{2}{*}{$\mathrm{NDFap}^{(2)}$} & In natura & $392.8 \mathrm{Aa}$ & 393.9Aa & 379.7Aa & 396.9Aa \\
\hline & Pre-dried & $371.1 \mathrm{Aa}$ & 383.1Aa & $388.7 \mathrm{Aa}$ & 406.9Aa \\
\hline \multirow{2}{*}{$\mathrm{ADF}^{(2)}$} & In natura & $314.9 \mathrm{Ba}$ & $351.2 \mathrm{Aa}$ & $332.3 \mathrm{ABa}$ & 344.9Aa \\
\hline & Pre-dried & $294.5 \mathrm{Ba}$ & $313.8 \mathrm{Bb}$ & $297.5 \mathrm{Bb}$ & $346.0 \mathrm{Aa}$ \\
\hline \multirow{2}{*}{ Cellulose $\mathrm{e}^{(2)}$} & In natura & $187.4 \mathrm{Aa}$ & $189.7 \mathrm{Aa}$ & $185.5 \mathrm{Aa}$ & 198.1Aa \\
\hline & Pre-dried & $186.9 \mathrm{Aa}$ & 196.9Aa & $180.2 \mathrm{Aa}$ & $198.0 \mathrm{Aa}$ \\
\hline \multirow{2}{*}{ Hemicellulose ${ }^{(2)}$} & In natura & $225.4 \mathrm{Aa}$ & $207.6 \mathrm{Aa}$ & $196.8 \mathrm{Ab}$ & $220.2 \mathrm{Aa}$ \\
\hline & Pre-dried & $229.1 \mathrm{Aa}$ & $214.2 \mathrm{Aa}$ & $259.8 \mathrm{Aa}$ & $223.1 \mathrm{Aa}$ \\
\hline \multirow{2}{*}{$\mathrm{ADL}^{(2)}$} & In natura & $127.5 \mathrm{Ba}$ & 161.4Aa & $146.8 \mathrm{ABa}$ & $146.8 \mathrm{ABa}$ \\
\hline & Pre-dried & $107.6 \mathrm{Bb}$ & $116.9 \mathrm{Bb}$ & $117.3 \mathrm{Bb}$ & $147.9 \mathrm{Aa}$ \\
\hline \multirow{2}{*}{$\operatorname{NDIP}^{(2)}$} & In natura & $125.5 \mathrm{Ba}$ & $133.6 \mathrm{ABa}$ & $123.5 \mathrm{Bb}$ & $140.2 \mathrm{Aa}$ \\
\hline & Pre-dried & $126.1 \mathrm{Aa}$ & $126.1 \mathrm{Aa}$ & $137.2 \mathrm{Aa}$ & $134.4 \mathrm{Aa}$ \\
\hline \multirow{2}{*}{$\mathrm{ADIP}^{(2)}$} & In natura & $43.6 \mathrm{Ca}$ & $55.8 \mathrm{ABa}$ & 48.0BCa & $56.8 \mathrm{Aa}$ \\
\hline & Pre-dried & $40.7 \mathrm{Ba}$ & $41.2 \mathrm{Bb}$ & $40.3 \mathrm{Bb}$ & $52.0 \mathrm{Aa}$ \\
\hline \multirow{2}{*}{$\begin{array}{l}\text { Nonfibrous carbohydrate } \\
\text { (NFC) })^{(2)}\end{array}$} & In natura & $248.8 \mathrm{Ab}$ & $255.8 \mathrm{Aa}$ & $275.0 \mathrm{Aa}$ & $245.3 \mathrm{Aa}$ \\
\hline & Pre-dried & 281.1Aa & $271.6 \mathrm{Aa}$ & $267.6 \mathrm{Aa}$ & $246.5 \mathrm{Aa}$ \\
\hline \multirow{2}{*}{$\begin{array}{l}\text { Fibrous carbohydrate } \\
(\mathrm{FC})^{(2)}\end{array}$} & In natura & 392.8Aa & 393.9Aa & 379.7Aa & 396.9Aa \\
\hline & Pre-dried & 371.1Aa & 383.1Aa & $388.8 \mathrm{Aa}$ & 406.9Aa \\
\hline \multirow{2}{*}{$\mathrm{TDN}^{(2)}$} & In natura & 499.0Ab & $458.7 \mathrm{Cb}$ & $484.6 \mathrm{Bb}$ & $456.5 \mathrm{Cb}$ \\
\hline & Pre-dried & $524.7 \mathrm{Aa}$ & $516.3 \mathrm{Ba}$ & $503.9 \mathrm{Ca}$ & $464.9 \mathrm{Da}$ \\
\hline
\end{tabular}

${ }^{(1)}$ Means followed by the equal letter, uppercases in the rows and lowercases in the columns, do not differ by Tukey's test, at 5\% probability. ${ }^{(2)} \mathrm{NDF}$, neutral detergent fiber; NDFap, neutral detergent fiber corrected for ash and protein; ADF, acid detergent fiber; ADL, acid digested lignin; NDIP, neutral detergent insoluble protein; ADIP, acid detergent insoluble protein; TDN, total digestible nutrients. ${ }^{(3)} \mathrm{WI}$, with bacterial inoculant; GC, ground corn; $\mathrm{GC}+\mathrm{I}$, ground corn + bacterial inoculant; WA, without additives. ${ }^{(2)}\left(\mathrm{g} \mathrm{kg}^{-1}\right)$ of DM. 
Mimosa caesalpiniifolia, which are part of the diet of ruminants in the Semiarid region (Santos et al., 2017). The NDF is an indicator of food quality, and high levels of NDF in the diet reduce the voluntary intake in ruminants by the filling effect (Pinho et al., 2018). However, according to Alves et al. (2016), the unavailability of fiber in both quantity and quality causes disturbances in the animal energy metabolism and can compromise the animal performance, interfering with the characteristics of end products.

The highest concentrations of acid detergent fiber (ADF) and acid digested lignin (ADL) were found in the $\mathrm{GC}, \mathrm{GC}+\mathrm{I}$, and WA treatments of in natura silage (Table 2). In pre-dried silage, the highest content of these compounds was obtained in the WA treatment. When the two forms of silage were compared, in nature silage was superior to pre-dried silage for: ADF, when subjected to the $\mathrm{GC}$ and $\mathrm{GC}+\mathrm{I}$ treatments; and ADL, when subjected to WI, GC, and GC+I (Table 2). $\mathrm{ADF}$, the most indigestible fraction of food, and lignin presented low or no digestibility, which influences the digestibility of plant cell wall components (Wanderley et al., 2012).

Neutral detergent insoluble protein (NDIP) and acid detergent insoluble protein (ADIP) content were higher in the treatments GC and WA in natura silage (Table 2). There was no difference for NDIP in the form of pre-dried silage. The treatment $\mathrm{GC}+\mathrm{I}$ had higher NDIP contents in pre-dried silage than that of in natura silage. Comparing the two forms of silage, there was a difference in the treatments $\mathrm{GC}$ and $\mathrm{GC}+\mathrm{I}$, in which ADIP concentrations were higher in natura silage than in pre-dried silage (Table 2). Attention should be paid to the levels of NDIP and ADIP because, if a considerable part of the crude protein of the feed is linked to the fibrous fraction, lignin becomes resistant to microorganism enzymes, that is, it is unavailable for microorganisms, which decreases digestibility of forage in the animals, affecting the efficiency of rumen microbial synthesis and the animal performance (Licitra et al., 1996; Nunes et al., 2016; Oliveira et al., 2020).

The total carbohydrate (TC) concentration in the in natura silage was higher in the $\mathrm{GC}+\mathrm{I}$ treatment, and the lowest TC content occurred in the WI treatment (Table 3). The treatments applied to the pre-dried silage form showed no differences in TC contents. When comparing both forms of silage, pre-dried silage subjected to the WI and WA treatments was superior to in natura silage. Moreover, fractions A + B1 (soluble fraction) and B2 (potentially degradable fiber) did not differ between treatments, nor silage forms (Table 3). The proportion of fraction B2 was higher than fractions $\mathrm{A}+\mathrm{B} 1$ and $\mathrm{C}$, which can be attributed to higher cellulose contents concerning the nonfibrous carbohydrates found in the evaluated silages, and, because of this, they may present a slow rate of ruminal degradation.

The content of fraction $\mathrm{C}$ (the most unavailable carbohydrate fraction) was the highest in the GC, $\mathrm{GC}+\mathrm{I}$, and WA treatments, and the lowest, in the WI treatment, both for in natura and pre-dried silages. When comparing the forms of silage, fraction $\mathrm{C}$ differed in the WI and GC treatments, being superior

Table 3. Carbohydrates and nitrogen compounds fractionation of the different treatments applied to silage of arboreal cotton [Gossypium hirsutum var. marie-galante (G.Watt) J.B.Hutch.] ${ }^{(1)}$.

\begin{tabular}{|c|c|c|c|c|c|}
\hline \multirow[t]{2}{*}{ Trait $^{(2)}$} & \multirow[t]{2}{*}{ Silage } & \multicolumn{4}{|c|}{ Treatment $^{(3)}$} \\
\hline & & WI & $\mathrm{GC}$ & $\mathrm{GC}+\mathrm{I}$ & WA \\
\hline & & & Carbc & ydrate & \\
\hline \multirow{2}{*}{$\mathrm{TC}^{(4)}$} & In natura & $641.6 \mathrm{Bb}$ & 649.7ABa & 654.7Aa & $642.2 \mathrm{ABb}$ \\
\hline & Pre-dried & 653.1Aa & 654.7Aa & 654.4Aa & $652.4 \mathrm{Aa}$ \\
\hline \multirow{2}{*}{$\begin{array}{l}\mathrm{A}+ \\
\mathrm{B} 1^{(5)}\end{array}$} & In natura & 387.7Aa & 393.6Аa & 420.6Aa & 381.8Aa \\
\hline & Pre-dried & $430.9 \mathrm{Aa}$ & 414.8Aa & 407.8Aa & $377.2 \mathrm{Aa}$ \\
\hline \multirow{2}{*}{$\mathrm{B} 2^{(5)}$} & In natura & 485.3Aa & 441.0Aa & 433.4Aa & 475.8Aa \\
\hline & Pre-dried & $460.1 \mathrm{Aa}$ & 459.0Aa & 464.2Aa & $476.3 \mathrm{Aa}$ \\
\hline \multirow{3}{*}{$C^{(5)}$} & In natura & $127.0 \mathrm{Ba}$ & $165.3 \mathrm{Aa}$ & $146.0 \mathrm{ABa}$ & $142.3 \mathrm{ABa}$ \\
\hline & Pre-dried & $108.0 \mathrm{Bb}$ & $126.1 \mathrm{ABb}$ & $130.0 \mathrm{ABa}$ & 146.4Aa \\
\hline & & \multicolumn{4}{|c|}{ Nitrogen compounds } \\
\hline \multirow{2}{*}{$\mathrm{CP}^{(4)}$} & In natura & $243.2 \mathrm{Aa}$ & 236.7ABa & $227.7 \mathrm{Ba}$ & $245.1 \mathrm{Aa}$ \\
\hline & Pre-dried & $232.7 \mathrm{Ab}$ & $233.1 \mathrm{Aa}$ & 235.6Aa & $231.8 \mathrm{Ab}$ \\
\hline \multirow{2}{*}{$\mathrm{A}^{(5)}$} & In natura & $162.8 \mathrm{ABa}$ & 174.6Aa & $125.9 \mathrm{Ba}$ & $140.6 \mathrm{ABa}$ \\
\hline & Pre-dried & $118.9 \mathrm{Ab}$ & 143.6Aa & $126.7 \mathrm{Aa}$ & 130.7Aa \\
\hline \multirow{2}{*}{$\begin{array}{l}\mathrm{B} 1+ \\
\mathrm{B} 2^{(5)}\end{array}$} & In natura & $321.4 \mathrm{ABa}$ & $265.6 \mathrm{Bb}$ & $330.2 \mathrm{Aa}$ & $287.4 \mathrm{ABa}$ \\
\hline & Pre-dried & 338.8Aa & 315.1Aa & $290.7 \mathrm{Aa}$ & $289.0 \mathrm{Aa}$ \\
\hline \multirow{2}{*}{$\mathrm{B} 3^{(5)}$} & In natura & 336.4Aa & 328.9Aa & $332.8 \mathrm{Ab}$ & $340.4 \mathrm{Aa}$ \\
\hline & Pre-dried & $367.3 \mathrm{Aa}$ & 364.0Aa & $411.5 \mathrm{Aa}$ & 355.8Aa \\
\hline \multirow{2}{*}{$C^{(5)}$} & In natura & $179.4 \mathrm{Ba}$ & 230.9Aa & $211.2 \mathrm{ABa}$ & $231.6 \mathrm{Aa}$ \\
\hline & Pre-dried & $175.0 \mathrm{Ba}$ & $177.3 \mathrm{Bb}$ & $171.1 \mathrm{Bb}$ & $224.4 \mathrm{Aa}$ \\
\hline
\end{tabular}

${ }^{(1)}$ Means followed by the equal letter, uppercases in the rows and lowercases in the columns, do not differ by Tukey's test, at $5 \%$ probability. ${ }^{(2)}$ Trait: $\mathrm{TC}$, total carbohydrate; $\mathrm{A}+\mathrm{B} 1$, soluble fraction; $\mathrm{B} 2$, potentially degradable fiber; $\mathrm{C}$, indigestible fiber; $\mathrm{CP}$, crude protein; $\mathrm{A}$, nonprotein nitrogen; $\mathrm{B} 1+\mathrm{B} 2$, high and medium nitrogen fraction ruminal degradation; $\mathrm{B} 3$, slow degrading nitrogen fraction; $\mathrm{C}$, unavailable nitrogen fraction. ${ }^{(3)} \mathrm{WI}$, with bacterial inoculant; $\mathrm{GC}$, ground corn; $\mathrm{GC}+\mathrm{I}$, ground corn + bacterial inoculant; WA, without additives. ${ }^{(4)}\left(\mathrm{g} \mathrm{kg}^{-1}\right)$ of DM. ${ }^{(5)}\left(\mathrm{g} \mathrm{kg}^{-1}\right)$ of TC. 
in in natura silage (Table 3). Lower values for this fraction are more desirable because fraction $\mathrm{C}$ is linked to carbohydrates unavailable for digestion. Forages with high levels of fraction $\mathrm{C}$ interfere with the ruminal repletion, due to the indigestible characteristic of this fraction, consequently affecting the animal feed intake (Mendoza et al., 2014).

Nitrogen fractionation of in natura silage showed higher concentration in fraction A in the GC treatment (Table 3). When forage has a high protein content and most of this protein is in fast degradation fractions (nonprotein nitrogenous compounds), it is necessary to supply a carbohydrate source with a high ruminal degradation rate to allow the microbial synthesis in the rumen to be efficient (Oliveira et al., 2020).

The fraction $\mathrm{B} 1+\mathrm{B} 2$ in natura silage showed the highest value in the $\mathrm{GC}+\mathrm{I}$ treatment. In pre-dried silage, this fraction did not differ between treatments (Table 3). Among the evaluated treatments, the WI, in the pre-dried silage, and the $\mathrm{GC}+\mathrm{I}$, in the in natura silage, showed the highest contents for the fraction $\mathrm{B} 1+\mathrm{B} 2$, thus having greater potential as a source of rumen digestible protein than the other treatments. The concentrations of fraction B3 did not differ for both in natura and pre-dried silages. In the comparison between the two silages, the GC+I treatment in the pre-dried silage was higher than that of in natura silage (Table 3). The higher content of fraction B3 obtained in the $\mathrm{GC}+\mathrm{I}$ treatment of pre-dried silage may interfere with a lower ruminal degradation, but the protein that escapes ruminal degradation may have high intestinal digestibility (rumen undegraded protein).

In fraction $\mathrm{C}$ (nitrogenous compounds), the highest levels in natura silage were observed in the treatments WA and GC. This result can be attributed to the N of this fraction that is most unavailable, as it is made up of proteins and $\mathrm{N}$ compounds linked to lignin, compounds of plant metabolism (tannins), and products derived from the chemical reaction of Maillard, which are resistant to microbial digestion and degradation (Sniffen et al., 1992). Thus, the higher concentrations of fraction $\mathrm{C}$ in $\mathrm{N}$ compounds, as well as the fraction $\mathrm{C}$ of the carbohydrates obtained in the treatment WA negatively influenced the in vitro dry matter

Table 4. In vitro gas production parameters and dry matter digestibility (IVDMD) of different treatments applied to silage of arboreal cotton [Gossypium hirsutum var. marie-galante (G.Watt) J.B.Hutch.] ${ }^{(1)}$.

\begin{tabular}{|c|c|c|c|c|c|}
\hline \multirow{2}{*}{ Trait $^{(2)}$} & \multirow{2}{*}{ Silage } & \multicolumn{4}{|c|}{ Treatment $^{(3)}$} \\
\hline & & WI & GC & $\mathrm{GC}+\mathrm{I}$ & WA \\
\hline \multirow{2}{*}{$\mathrm{Vt}_{1}$} & In natura & $114.2 \mathrm{Cb}$ & $130.2 \mathrm{ABa}$ & $135.9 \mathrm{Aa}$ & $121.1 \mathrm{BCa}$ \\
\hline & Pre-dried & $125.3 \mathrm{ABa}$ & $137.2 \mathrm{Aa}$ & $126.1 \mathrm{ABa}$ & $116.8 \mathrm{Ba}$ \\
\hline \multirow{2}{*}{$\mathrm{Vt}_{2}$} & In natura & $121.1 \mathrm{Cb}$ & $141.7 \mathrm{ABa}$ & $143.3 \mathrm{Aa}$ & $129.0 \mathrm{BCa}$ \\
\hline & Pre-dried & $133.4 \mathrm{ABa}$ & $145.5 \mathrm{Aa}$ & $134.4 \mathrm{ABa}$ & $126.4 \mathrm{Ba}$ \\
\hline \multirow{2}{*}{ Vf1 } & In natura & $17.97 \mathrm{Ba}$ & $20.50 \mathrm{ABb}$ & $26.66 \mathrm{Aa}$ & $22.8 \mathrm{ABa}$ \\
\hline & Pre-dried & $18.72 \mathrm{Ba}$ & $28.86 \mathrm{Aa}$ & $21.38 \mathrm{Ba}$ & $18.70 \mathrm{Ba}$ \\
\hline \multirow{2}{*}{ kd1 } & In natura & $0.177 \mathrm{Aa}$ & $0.118 \mathrm{Aa}$ & $0.120 \mathrm{Aa}$ & $0.117 \mathrm{Aa}$ \\
\hline & Pre-dried & $0.145 \mathrm{Aa}$ & $0.114 \mathrm{Aa}$ & $0.135 \mathrm{Aa}$ & $0.142 \mathrm{Aa}$ \\
\hline \multirow{2}{*}{ Vf2 } & In natura & $103.2 \mathrm{Cb}$ & $121.2 \mathrm{Aa}$ & $116.6 \mathrm{ABa}$ & $106.2 \mathrm{BCa}$ \\
\hline & Pre-dried & 114.6Aa & $116.7 \mathrm{Aa}$ & 113.0Aa & 107.6Aa \\
\hline \multirow{2}{*}{$\mathrm{kd} 2$} & In natura & $0.032 \mathrm{Aa}$ & $0.029 \mathrm{Bb}$ & $0.031 \mathrm{Aa}$ & $0.030 \mathrm{ABa}$ \\
\hline & Pre-dried & $0.031 \mathrm{Aa}$ & $0.030 \mathrm{Aa}$ & $0.030 \mathrm{Aa}$ & $0.030 \mathrm{Aa}$ \\
\hline \multirow{2}{*}{ Lag time } & In natura & $13.21 \mathrm{Aa}$ & $12.63 \mathrm{Aa}$ & $12.29 \mathrm{Aa}$ & $12.30 \mathrm{Aa}$ \\
\hline & Pre-dried & $12.92 \mathrm{Aa}$ & $12.58 \mathrm{Aa}$ & $12.64 \mathrm{Aa}$ & $10.75 \mathrm{Aa}$ \\
\hline \multirow{2}{*}{$\begin{array}{l}\text { IVDMD } \\
\left(\mathrm{g} \mathrm{kg}^{-1} \text { of DM }\right)\end{array}$} & In natura & $443.3 \mathrm{Aa}$ & 444.7Aa & $458.3 \mathrm{Aa}$ & $427.9 \mathrm{Ba}$ \\
\hline & Pre-dried & $446.3 \mathrm{Aa}$ & $446.1 \mathrm{Aa}$ & $454.2 \mathrm{Aa}$ & $427.5 \mathrm{Ba}$ \\
\hline
\end{tabular}

${ }^{(1)}$ Means followed by the equal letter, uppercases in the rows and lowercases in the columns, do not differ by Tukey's test, at $5 \%$ probability. ${ }^{(2)} \mathrm{Vt}_{1}$, total observed volume ( $\left.\mathrm{mL} \mathrm{g}^{-1} \mathrm{DM}\right) ; \mathrm{Vt}_{2}$, total volume $\left(\mathrm{mL} \mathrm{g}^{-1} \mathrm{DM}\right)$ found from model; Vf1, volume $(\mathrm{mL})$ from gases produced by the degradation of the fraction $\mathrm{A}+\mathrm{B} 1$ of Cornell Sistem (NFC) fast fermentation; $\mathrm{kdl}\left(\% \mathrm{~h}^{-1}\right)$, degradation rate of fast digestion fraction (NFC); Vf2, volume of gases produced by the degradation of fraction B2 of Cornell Sistem (FC), slow degradation; $k d 2\left(\% \mathrm{~h}^{-1}\right)$, specific rate of gas production by degradation of fraction $\mathrm{B} 2$ (FC); IVDMD, in vitro dry matter digestibility. ${ }^{(3)} \mathrm{WI}$, with bacterial inoculant; GC, ground corn; GC+I, ground corn + bacterial inoculant; WA, without additives. 
digestibility (IVDMD), in the two silage forms that did not receive additive (Table 4). However, the total digestible nutrient (TDN) value of the WI treatment was higher than those in the other treatments in both silage forms (Table 2). This result can be attributed to the lower levels of ADL, fraction $\mathrm{C}$ of the carbohydrate, and nitrogenous compounds.

The total volume of gas observed for the variables $\mathrm{Vt1}, \mathrm{Vt} 2$, Vf1, and Vf2 in natura and pre-dried silages for $\mathrm{GC}+\mathrm{I}$ and $\mathrm{GC}$ treatments were higher than those of the other treatments (Figure 1 and Table 4). These results are attributed to the higher total carbohydrate (TC) for $\mathrm{Vt1}$ and $\mathrm{Vt} 2$. The gas volume of the variable $\mathrm{Vt1}$ showed values close to that of Vt2, confirming the fit of the applied model (Table 4). For Vf1 and
Vf2 the largest volumes of gases produced can be attributed to $\mathrm{A}+\mathrm{B} 1$ and $\mathrm{B} 2$ carbohydrate fractions, respectively. Thus, the carbohydrates in the fraction B2 of these treatments showed a higher degradation potential. The highest final volume of gas had a greater availability of nutrients for rumen microorganisms (Oliveira et al., 2020).

The highest degradation rate in the variable $\mathrm{kd} 2$ was observed in the WI, GC+I, and WA treatments of in nature silage (Table 4). The highest value can be attributed to the lower levels of ADL and fraction $\mathrm{C}$ of carbohydrates. Between the two forms of silage, $\mathrm{kd} 2$ was superior in pre-dried silage subjected to the GC treatment. The degradation rate kd1 did not differ between the two forms of silage.

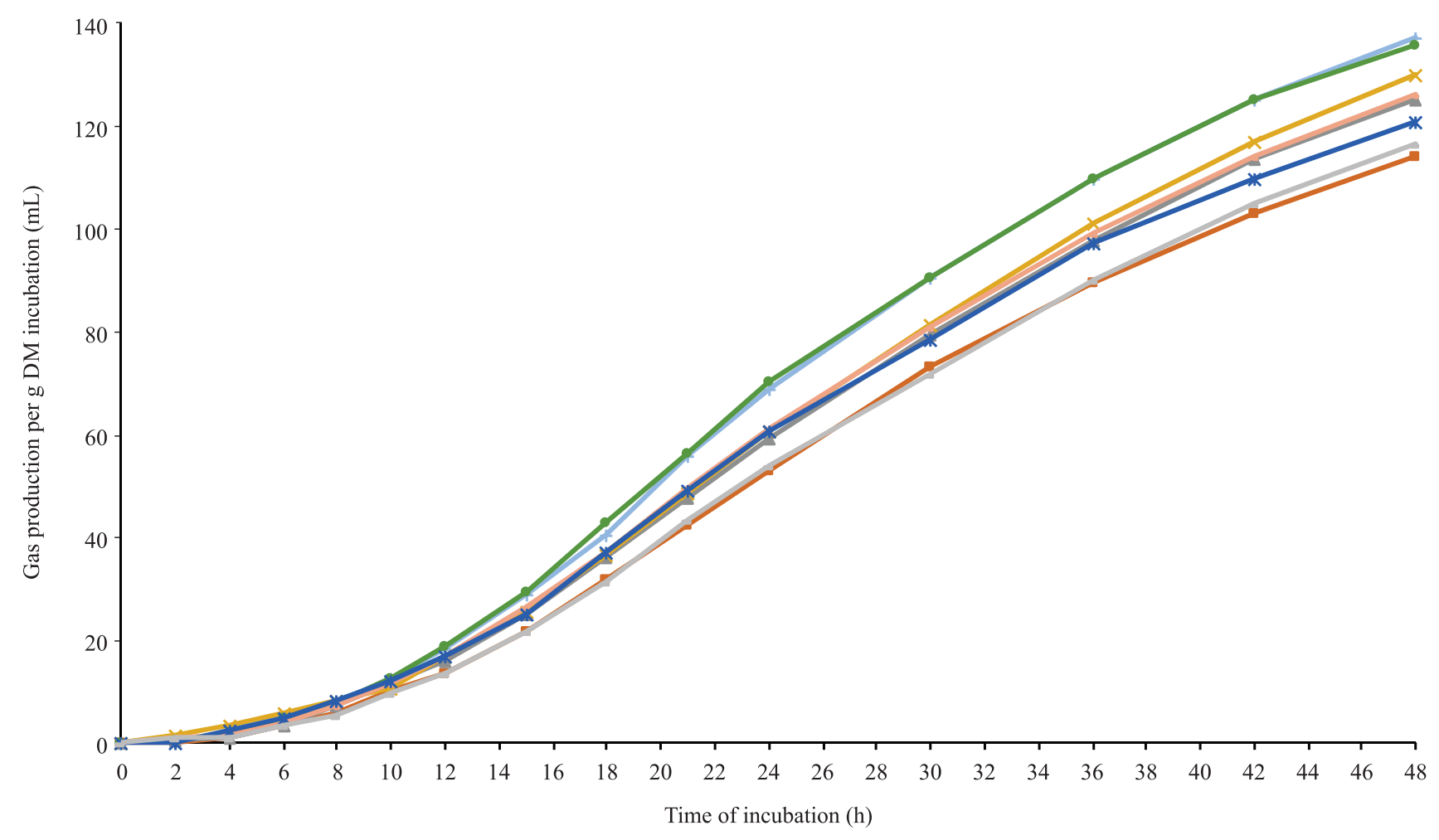

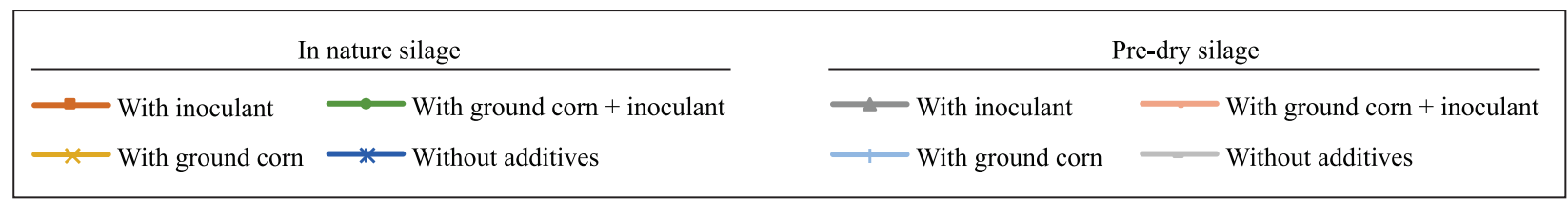

Figure 1. Total volume of gases produced during in vitro incubation in the different treatments applied to silage of arboreal cotton [Gossypium hirsutum var. marie-galante (G.Watt) J.B.Hutch.]. 


\section{Conclusions}

1. Arboreal cotton (Gossypium hirsutum var. mariegalante) silage associated with the bacterial inoculant or inoculant with $2 \%$ ground corn, has a better fermentation profile, besides improving the energy and nutritional value, both in nature and pre-dried forms of silage.

2. In natura silage shows a greater advantage to the rural producer than the pre-dried silage because it is less laborious and does not depend on climatic conditions for pre-drying.

\section{Acknowledgments}

To Conselho Nacional de Desenvolvimento Científico e Tecnológico (CNPq), for funding this research; and to Coordenação de Aperfeiçoamento de Pessoal de Nível Superior (Capes, finance code 001) for postgraduate scholarship grant (Process number: 88887.319732/2019-00).

\section{References}

ALVES, A.R.; PASCOAL, L.A.F.; CAMBUÍ, G.B.; TRAJANO, J. da S.; SILVA, C.M. da; GOIS, G.C. Fibra para ruminantes: aspecto nutricional, metodológico e funcional. Publicações em Medicina Veterinária e Zootecnia, v.10, p.568-579, 2016. DOI: https://doi.org/10.22256/pubvet.v10n7.568-579.

ANDRADE, A.P.; QUADROS, D.G. de; BEZERRA, A.R.G.; ALMEIDA, J.A.R.; SILVA, P.H.S.; ARAÚJO, J.A.M. Aspectos qualitativos da silagem de capim-elefante com fubá de milho e casca de soja. Semina: Ciências Agrárias, v.33, p.1209-1218, 2012. DOI: https://doi.org/10.5433/1679-0359.2012v33n3p1209.

BERGAMASCHINE, A.F.; PASSIPIÉRI, M.; VERIANO FILHO, W.V.; ISEPON, O.J.; CORREA, L. de A. Qualidade e valor nutritivo de silagens de capim-marandu (B. brizantha $\mathrm{cv}$. Marandu) produzidas com aditivos ou forragem emurchecida. Revista Brasileira de Zootecnia, v.35, p.1454-1462, 2006. DOI: https://doi.org/10.1590/S1516-35982006000500027.

BEZERRA, H.F.C.; SANTOS, E.M.; OLIVEIRA, J.S.; CARVALHO, G.G.P.; PINHO, R.M.A.; SILVA, T.C.; PEREIRA, G.A.; CASSUCE, M.R.; ZANINE, A.M. Fermentation characteristics and chemical composition of elephant grass silage with ground maize and fermented juice of epiphytic lactic acid bacteria. South African Journal of Animal Science, v.49, p.522533, 2019. DOI: https://doi.org/10.4314/sajas.v49i3.13.

CAMPOS, F.S.; GOIS, G.C.; VICENTE, S.L.A.; MACEDO, A. de; MATIAS, A.G. da S. Alternativa de forragem para caprinos e ovinos criados no semiárido. Nutritime Revista Eletrônica, v.14, p.5004-5013, 2017.
CHANEY, A.L.; MARBACH, E.P. Modified reagents for determination of urea and ammonia. Clinical Chemistry, v.8, p.130-132, 1962. DOI: https://doi.org/10.1093/clinchem/8.2.130.

CORRÊA, A.A.; BACKES, A.A.; FAGUNDES, J.L.; BARBOSA, L.T.; SOUSA, B.M.L.; OLIVEIRA, V.S.; MOREIRA, L.A. Caracterização da silagem da rama da batata doce emurchecida e adicionada de fubá de milho como aditivo. Boletim da Indústria Animal, v.73, p.272-280, 2016. DOI: https://doi.org/10.17523/bia. v73n4p272.

COUTINHO, J.J. de O.; COURA, R.A.N.; RODRIGUES, L.M.; ATHAYDE, A.A.R. Efeito de aditivo em silagens de leguminosas forrageiras. Ciência et Praxis, v.8, p.53-57, 2015.

HELRICH, K. (Ed.). Official Methods of Analysis of the Association of Official Analytical Chemists. $15^{\text {th }}$ ed. Arlington: AOAC, 1990. Official Methods 920.39, 930.15, 942.05, 954.01.

HOLDEN, L.A. Comparison of methods of in vitro dry matter digestibility for ten feeds. Journal of Dairy Science, v.82, p.1791-1794, 1999. DOI: https://doi.org/10.3168/jds.S00220302(99)75409-3.

LICITRA, G.; HERNANDEZ, T.M.; VAN SOEST, P.J. Standardization of procedures for nitrogen fractionation of ruminants feeds. Animal Feed Science and Technology, v.57, p.347-358, 1996. DOI: https://doi.org/10.1016/03778401(95)00837-3.

MCDONAld, P.; HENDERSON, A.R.; HERON, S.J.E. The Biochemistry of Silage. $2^{\text {nd }}$ ed. Marlow: Chalcombe, 1991. 340p.

MENDOZA, G.D.; LOERA-CORRAL, O.; PLATA PÉREZ, F.X.; HERNÁNDEZ-GARCÍA, P.A.; RAMÍREZ-MELLA, M. Considerations on the use of exogenous fibrolytic enzymes to improve forage utilization. The Scientific World Journal, v.2014, art.247437, 2014. DOI: https://doi.org/10.1155/2014/247437.

MENEZES, I.P.P. de; HOFFMANN, L.V.; BARROSO, P.A.V. Genetic characterization of cotton landraces found in the Paraíba and Rio Grande do Norte states. Crop Breeding and Applied Biotechnology, v.15, p.26-32, 2015. DOI: https://doi.org/10.1590/1984-70332015v15n1a4.

MENEZES, I.P.P. de; HOFFMANN, L.V.; LIMA, T.H. de; SILVA, A.R. da; LUCENA, V.S.; BARROSO, P.A.V. Genetic diversity of arboreal cotton populations of the Brazilian semiarid: a remnant primary gene pool for cotton cultivars. Genetics and Molecular Research, v.16, art. 16039659, 2017. DOI: https://doi.org/10.4238/ gmr16039659.

MERTENS, D.R. Gravimetric determination of amylase-treated neutral detergent fiber in feeds with refluxing in beakers or crucibles: collaborative study. Journal of AOAC International, v.85, p.1217-1240, 2002.

MORAES, G.S. de O.; GUIM, A.; TABOSA, J.N.; CHAGAS, J.C.C.; ALMEIDA, M. de P.; FERREIRA, M. de A. Cactus [Opuntia stricta (Haw.) Haw] cladodes and corn silage: how do we maximize the performance of lactating dairy cows reared in semiarid regions? Livestock Science, v.221, p.133-138, 2019. DOI: https://doi.org/10.1016/j.livsci.2019.01.026. 
NRC. National Research Council. Nutrient requirements of dairy cattle. $7^{\text {th }}$ rev. ed. Washington: National Academic Press, 2001. 381p. DOI: https://doi.org/10.17226/9825.

NUNES, A.T.; CABRAL, D.L.V.; AMORIM, E.L.C.; SANTOS, M.V.F. dos; ALBUQUERQUE, U.P. Plants used to feed ruminants in semiarid Brazil: a study of nutritional composition guided by local ecological knowledge. Journal of Arid Environments, v.135, p.96-103, 2016. DOI: https://doi.org/10.1016/j. jaridenv.2016.08.015.

OLIVEIRA, L.P. de; MAGALHÃES, A.L.R.; TEODORO, A.L.; ANDRADE, A.P. de; SANTOS, K.C. dos; ARAÚJO, G.G.L de. Chemical characteristics, degradation kinetics and gas production of arboreal species for ruminants. Revista Ciência Agronômica, v.51, e20196707, 2020. DOI: https://doi.org/10.5935/18066690.20200047 .

PINHO, R.M.A.; SANTOS, E.M.; OLIVEIRA, J.S. de; CARVALHO, G.G.P. de; SILVA, T.C. da; MACÊDO, A.J. da S.; CORRÊA, Y.R.; ZANINE, A. de M.Z. Does the level of forage neutral detergent fiber affect the ruminal fermentation, digestibility and feeding behavior of goats fed cactus pear? Animal Science Journal, v.89, p.1424-1431, 2018. DOI: https://doi.org/10.1111/asj.13043.

PINHO, R.M.A.; SANTOS, E.M.; RODRIGUES, J.A.S.; MACEDO, C.H.O.; CAMPOS, F.S.; RAMOS, J.P. de F.; BEZERRA, H.F.C.; PERAZZO, A.F. Avaliação de genótipos de milheto para silagem no semiárido. Revista Brasileira de Saúde e Produção Animal, v.14, p.426-436, 2013. DOI: https://doi.org/10.1590/S1519-99402013000300003.

SANTOS, H.G. dos; JACOMINE, P.K.T.; ANJOS, L.H.C. dos; OLIVEIRA, V.Á. de; LUMBRERAS, J.F.; COELHO, M.R.; ALMEIDA, J.A. de; ARAÚJO FILHO, J.C. de; OLIVEIRA, J.B. de; CUNHA, T.J.F. Sistema brasileiro de classificação de solos. 5.ed. rev. e ampl. Brasília: Embrapa, 2018. E-book.

SANTOS, K.C.; MAGALHÃES, A.L.R.; SILVA, D.K.A.; ARAÚJO, G.G.L.; FAGUNDES, G.M.; YABARRA, N.G.; ABDALLA, A.L. Nutritional potential of forage species found in Brazilian Semiarid region. Livestock Science, v.195, p.118-124, 2017. DOI: https://doi.org/10.1016/j.livsci.2016.12.002.

SCHOFIELD, P.; PITT, R.E.; PELL, A.N. Kinetics of fiber digestion from in vitro gas production. Journal of Animal Science, v.72, p.2980-2991, 1994. DOI: https://doi.org/10.2527/1994.72112980x.
SILVA, E.T. dos S.; MELO, A.A.S. de; FERREIRA, M. de A.; OLIVEIRA, J.C.V. de; SANTOS, D.C. dos; SILVA, R.C.; INÁCIO, J.G. Acceptability by Girolando heifers and nutritional value of erect prickly pear stored for different periods. Pesquisa Agropecuária Brasileira, v.52, p.761-767, 2017. DOI: https://doi.org/10.1590/S0100-204X2017000900008.

SILVA, L.M. da; FAGUNDES, J.L.; VIEGAS, P.A.A.; MUNIZ, E.N.; RANGEL, J.H. de A.; MOREIRA, A.L.; BACKES, A.A. Produtividade da palma forrageira cultivada em diferentes densidades de plantio. Ciência Rural, v.44, p.2064-2071, 2014. DOI: https://doi.org/10.1590/0103-8478cr20131305.

SILVA, M.D.A.; CARNEIRO, M.S. de S.; PINTO, A.P.; POMPEU, R.C.F.F.; SILVA, D.S.; COUTINHO, M.J.F.; FONTENELE, R.M. Avaliação da composição químico-bromatológica das silagens de forrageiras lenhosas do semiárido brasileiro. Semina: Ciências Agrárias, v.36, p.571-578, 2015. DOI: https://doi.org/10.5433/1679-0359.2015v36n1p571.

SNIFFEN, C.J.; O'CONNOR, J.D.; VAN SOEST, P.J.; FOX, D.G.; RUSSEL, J.B. A net carbohydrate and protein system for evaluating cattle diets: II. Carbohydrate and protein availability. Journal of Animal Science, v.70, p.3562-3577, 1992. DOI: https://doi.org/10.2527/1992.70113562x.

THEODOROU, M.K.; WILLIAMS, B.A.; DHANOA, M.S.; McALLAN, A.B.; FRANCE, J. A simple gas production method using a pressure transducer to determine the fermentation kinetics of ruminant feed. Animal Feed Science and Technology, v.48, p.185-197, 1994. DOI: https://doi.org/10.1016/0377-8401(94)901716.

TILLEY, J.M.A.; TERRY, R.A. A two-stage technique for the in vitro digestion of forage crops. Grass and Forage Science, v.18, p.104-111, 1963. DOI: https://doi.org/10.1111/j.1365-2494.1963. tb00335.x.

VAN SOEST, P.J.; ROBERTSON, J.B.; LEWIS, B.A. Methods for dietary fiber, neutral detergent fiber, and nonstarch polysaccharides in relation to animal nutrition. Journal of Dairy Science, v.74, p.3583-3597, 1991. DOI: https://doi.org/10.3168/jds. S0022-0302(91)78551-2.

WANDERLEY, W.L.; FERREIRA, M. de A.; BATISTA, A.M.V.; VÉRAS, A.S.C.; BISPO, S.V.; SILVA, F.M. da; SANTOS, V.L.F. dos. Consumo, digestibilidade e parâmetros ruminais em ovinos recebendo silagens e fenos em associação à palma forrageira. Revista Brasileira de Saúde e Produção Animal, v.13, p.444-456, 2012. DOI: https://doi.org/10.1590/S1519-99402012000200013. 